\title{
Max Weber was Right about the Preconditions, Just Wrong about Japan: The Japanese Ethic and its Spirit of Capitalism
}

\author{
A.J. Jacobs*
}

East Carolina University, Department of Sociology, 405A Brewster, Mail Slot \#567, Greenville, NC 27858, USA

\begin{abstract}
Max Weber claimed that while Protestantism provided the proper ethos necessary to spur capitalism, Eastern religions did not. Japan's economic success has belied his hypothesis, and while there have been various theories explaining its rise, perhaps Weber's own claims regarding the connection between embeddedness and capitalism best explain Japan's rise. Simply put, Japanese capitalism was born and has evolved within a politico-economic-cultural context which has long encouraged hard work and asceticism, and which has had a rich 400-year plus history of entrepreneurship. Combined, these factors have constituted a Weberian-like Japanese Ethic which, along with its vaunted national industrial policy, has spawned and propelled its incredible economic growth since the late- $19^{\text {th }}$ Century. This article briefly chronicles the evolution of the three main tenets of the "Japanese ethic" - long working hours, high savings rates, and private, profitdriven entrepreneurship. In doing so, it shows how Weber was both right about the necessary embedded preconditions for capitalism, and wrong about Japan's ability to cultivate such an ethic.
\end{abstract}

Keywords: Japan, Japanese Capitalism, Weber, Protestant ethic.

\section{INTRODUCTION}

Max Weber claimed that whereas Protestantism fostered the proper ethic to spur capitalism, the religions of East Asian nations did not. Weber was correct in concluding that hard work, asceticism, and a strong entrepreneurial spirit were necessary preconditions to capitalism. However, what he was incorrect about was Japan's ability to develop such an ethic. This was curious, because in his time, Japan was the world's most economically and technologically advanced East Asian and Confucian-based nation. Its incredible economic rise and success since the late- $19^{\text {th }}$ Century has provided further evidence of the error of Weber hypothesis.

While there have been various theories which have attempted to explain Japan's emergence, perhaps Weber's own constructs best explained Japan's rise. Simply put, similar to Weber's Protestant ethic, Japanese capitalism was spawned in the $19^{\text {th }}$ Century and has evolved ever since within a politico-economic-cultural context which has long encouraged long working hours (hard work), and high savings rates (asceticism). It also has been, for more than 400 years, a fertile crucible for private, profit-driven entrepreneurship.

Long working hours have been the result of a number of factors. Most prominent among them have been: 1) a 'catchup' nationalist ideology, first instilled during the 1868 Meiji Restoration; 2) a hegemonic politico-social context which has stressed filial piety; and 3) a post-World War II segmented internal labor market, which has both demanded devotion to firm and has severely inhibited labor mobility.

*Address correspondence to this author at the East Carolina University, Department of Sociology, 405A Brewster, Mail Slot \#567, Greenville, NC 27858, USA; Tel: 252-328-1933; Fax: 252-328-4837;

E-mail: drajjacobs@yahoo.com
Among the embedded factors influencing its high savings rates have been: 1) a relatively 'small' government as compared with Anglo nations, such as the USA and UK, especially in relation to national defense; 2) a compensation system which has deferred a sizable portion of worker salary through semi-annual bonuses; 3) an under-financed social security system; and 4) national government policies that have severely suppressed consumption, such as through strict regulations on consumer credit. Finally, at the time of Weber's writing, Japan already had a well established merchant class adroit at exploiting its rational money economy. $\mathrm{Nu}$ merous good examples of this more than 400-year rich history of profit-driven entrepreneurship can be found throughout Japan.

Together, hard work, asceticism, and entrepreneurialism have constituted the main ingredients of Japan's Weberianlike ethic, which, along with its vaunted national industrial policy, has transformed it into the world's second largest economy. Drawing on currently available data and literature, this article briefly chronicles the three main tenets of the 'Japanese Ethic' - long working hours, high savings rates, and a 400-year plus history of private, profit-driven entrepreneurship. In the process, it shows how Weber was both right about the necessary embedded preconditions to spur capitalism and wrong about Japan's ability to cultivate such an ethic. As such, its findings should prove of interest to scholars of Weberian theory and of Japan.

\section{WEBER'S PROTESTANT ETHIC AND JAPAN}

In contrast to Marx, Weber believed that the economic system present within a given society could best be understood through the historical analysis of its culture and em- 
bedded superstructure [1-11]. ${ }^{1} \mathrm{He}$ was especially fascinated with the influence of religion on economic action [3]. In The Protestant Ethic and the Spirit of Capitalism, published in 1905 , Weber [12] attempted to explain why modern capitalism had developed more rapidly in Protestant countries than in others [also see 13-16]. Here, Weber [12] defined capitalism as an economic system based on money, not bartering, in which the underlying premises were: 1) the rational and peaceful pursuit of profit by private individuals and businesses; 2) the expectation of profit through exchange; and 3) the utilization of goods, services, and money as a means of acquisition and accumulation. For Weber, an individualistic, private capitalist entrepreneur or enterprise represented a person or firm who/which purposefully took full advantage of available opportunities for profit-making, realizing that if they did not, their business would cease to exist [12].

Weber argued that Protestant ethos had created the prime conditions necessary for capitalism to flourish in the West. According to Weber, Protestant sects, particularly Calvinism, first and foremost emphasized asceticism (living a modest life and abstaining from spending your earnings on unnecessary material objects). Secondly, he claimed that the Calvinists interpreted the concept of a job/work, as a Biblical 'calling,' a duty unto God and proof of genuine faith in the almighty. In turn, working long hours, and any subsequent wealth achieved and saved from such hard work, were interpreted by them as a sign of being in the good graces of, and as a gift from, God [12-16]. Finally, Weber maintained that in addition to making a person a good Christian, the Protestant ascetic and 'calling' to work had provided Western nations with the best climate possible to provoke an entrepreneurial 'spirit of capitalism.' Combined, these three elements made it possible to accumulate more wealth through the productive investment of capital, and in turn, capitalism to expand and thrive [12].

In contrast to Protestantism, Weber argued that East Asian religions, such as Confucianism and Buddhism, prevalent in China, Korea, and Japan, were too firmly grounded in taboo and kinship ties to foster the development of capitalism [4, 5, 13-17]. Moreover, he thought that unlike Puritan formal rationality, Confucian substantive rationality, which stresses collectivism, was incompatible with the development of economic individualism, and thereby, inhibited the emergence of the proper entrepreneurial spirit necessary to foster capitalism [4]. He said that while John Wesley taught his followers that frugality and economic success were both evidence of righteousness, the Confucian nations, such as Japan, accorded merchants very low status, and frowned upon thrift, even viewing it as hoarding. Instead, the ideal Confucian was thought to be a learned gentleman of grace and dignity, who above all, desired 'salvation' from ignorance/a lack of education. As a result, in such societies, ritual and the goal of self-perfection superseded any desire for individual wealth.

From this assessment, Weber concluded that as long as Confucianism was dominant, East Asian societies would

\footnotetext{
'Marx defined the 'base' as essentially the mode of production or economic system in place within a society, such as capitalism, socialism, or communism. This included its forces and social relations of production. Conversely, he defined superstructure as society's political-socio-cultural institutions, such as its ideology, ethos, politics, religious and legal doctrine, and related systems and institutions $[1,7]$.
}

always lack the necessary economic rationality and entrepreneurial spirit that had energized the modern money-based capitalist economies of the Western Anglo-Protestant countries [13-17]. However, by lumping all East Asian nations together in his typology, what Weber ignored was the fact that, whereas Chinese, Japanese, and South Korean ethos were all heavily influenced by the Analects of Confucius, each society also was forcefully shaped by its particular historical, political, cultural, and geographic context. As a result, both the style of Confucianism, and the degree to which its tenets were adapted, varied among the three societies, with each tailoring its principles to best fit its particular context.

For example, Shintoism, which is indigenous to Japan, and characterized by ancestor worship, among other things, impacted those aspects of Confucianism which were integrated into that nation, as compared with China and Korea. Therefore, whereas Chinese Confucianism stressed benevolence, Japanese Confucianism was based upon a trinity of values - loyalty, filial piety, and duty - which did not prohibit money-making and accumulation, as long as merchants remained loyal to their local lord or nation [4-7].

Lastly, Japan's trinity of values, along with its strong fear of outside destructive forces, especially from the West, led its military government to close its borders for more than 200 years, in order to preserve and develop Japanese society from within. Isolation also served to foster and protect domestic entrepreneurs from outside competition, and helped to grow nascent domestic market-oriented money economy. During the Meiji Period, fear of foreign influences also fueled an extreme sense of nationalism, including economic nationalism with loyal private capitalists (another Weberian requirement to capitalism). As will be discussed, this played an important role in shaping Japanese capitalism, and in promoting a devotion to firm, asceticism, and entrepreneurship among the Japanese populace in the post-war last period [4].

In other words, upon deeper investigation, it becomes clear that many of the same values and beliefs that Weber described in his Protestant Ethic have long been present in Japan. It is just that the Japanese Ethic of long working hours, high savings rates, and entrepreneurship has been guided by that nation's particular nested context, rather than the one specific 'calling' he ascribed to the Calvinists. To put it another way, in his writings on Asia, Weber failed to apply his own basic rule of inquiry: how an economic system within a particular society was uniquely shaped by its history, culture, and other embedded superstructure.

As the following sections chronicle, although guided by a different set of ideological principles, the same basic tenets of capitalist development which Weber attributed exclusively to Protestantism, hard work, asceticism, and profitoriented, private entrepreneurship, were already long present in Japan at the time of his writings in the early $20^{\text {th }}$ Century. In fact, evidence suggests that all three elements were among the guiding tenets of Japanese entrepreneurs for more than 400 years, especially among the merchants of its historic commercial capital, Osaka, its neighboring city Sakai (both in Osaka Prefecture), and in the regional provinces of Ise (now in Mie Prefecture) and Omi (now Shiga Prefecture). The same can be said for a rational money economy, which 
has been present in Japan since the $17^{\text {th }}$ Century, if not even earlier.

In sum, both the scholarship and available data to be presented suggest that while Weber may have been right regarding the necessary preconditions within a given society to fuel the development of capitalism - hard work, asceticism, and entrepreneurship - he was wrong about Japan and its ability to cultivate such an ethic. This conclusion also represents the significance, value, and/or novelty of this article to the scholarly literature, as it shows how Weber's own emphasis regarding the influence of embeddedness/superstructure on economic action, refutes his own hypothesis concerning Japan. It also calls into question his theory regarding the ability of non-Protestant religions, in general, to foster capitalism.

\section{HARD WORK IN JAPAN: CATCH-UP NATIONAL- ISM, LOYALTY, AND LIMITED LABOR MOBILITY EQUALS LONG HOURS}

One of the best examples of how the Japanese Ethic has mirrored Weber's Protestant Ethic has been its citizens' willingness and propensity to work long hours. Of course, the major difference between the Japanese and Weber's Calvinists has been that the former have not been driven by a quest for personal salvation, but rather by an embedded context which has promoted individual sacrifice and devotion to master, superior, company, and nation. Although crossnational data comparisons have their limitations, due to inconsistencies in data collection methods among government agencies in different countries, evidence clearly suggests that, at least since the beginning of the $20^{\text {th }}$ Century, Japanese workers have been equally as committed, if not more so, to the concept of work, as their counterparts in the USA and UK, the two nations that have represented Weber's prototypical examples of his Protestant ethic $[12,18]$.

According to the earliest data on hours worked published by Japanese Government [19], in 1905, the publication year of Weber's Protestant Ethic and the Spirit of Capitalism, the average Japanese worker toiled approximately 3,100 hours annually. As shown in Fig. (1), this total was approximately 400 hours a year more than the typical American worker at that time. Hours worked in Japan gradually fell to around 2,900 annually in 1930 , making it similar to the average American worker in the 1870s [20]. It then re-accelerated to around 3,000 in 1940 and then 3,200 in 1945, the end of World War II. This translated into approximately 1,000 more hours worked by the average Japanese worker than the average American worker at the time.

Immediately after the War, the annual hours of the average Japanese worker dramatically fell to 2,200 hours, before rising again steadily to a post-war peak of 2,425 in 1960 (Fig. 1). It is important to note, however, that after 1947, the Japanese Ministry of Labor began reporting only data for firms of 30 or more employees; that is, these post-war totals would have been measurably higher if all firms were included. Regardless, even with this undercount, at the time, Japanese labor was still working an average 400 hours a year more than the typical American worker, or the equivalent of an extra ten 40-hour weeks. This disparity would close only slightly during the 1960s [20-24].

In the 1970 s and 1980 s, despite the nation becoming the world's second largest economy, at roughly 2,100 annual hours, Japanese labor was still working more than 300 hours per year longer than their cohorts in the USA and UK. This situation began to change in the 1990s, following nearly two decades of internal political debate and foreign pressure to reform Japan's notoriously long, six-day work week. This process began in June 1979, when the country's Minister of Labor, Yukoh Kurihara declared that the government had set a goal of putting the country's work-force on a five-day work-week by 1985 .

Nevertheless, it was not until after a 1985 report by a Ministry of Labor committee showed that roughly 40 percent of Japanese labor force was still typically working more than 45 hours per week, that action was finally taken to revise Japanese labor practices. This came in the form of revisions

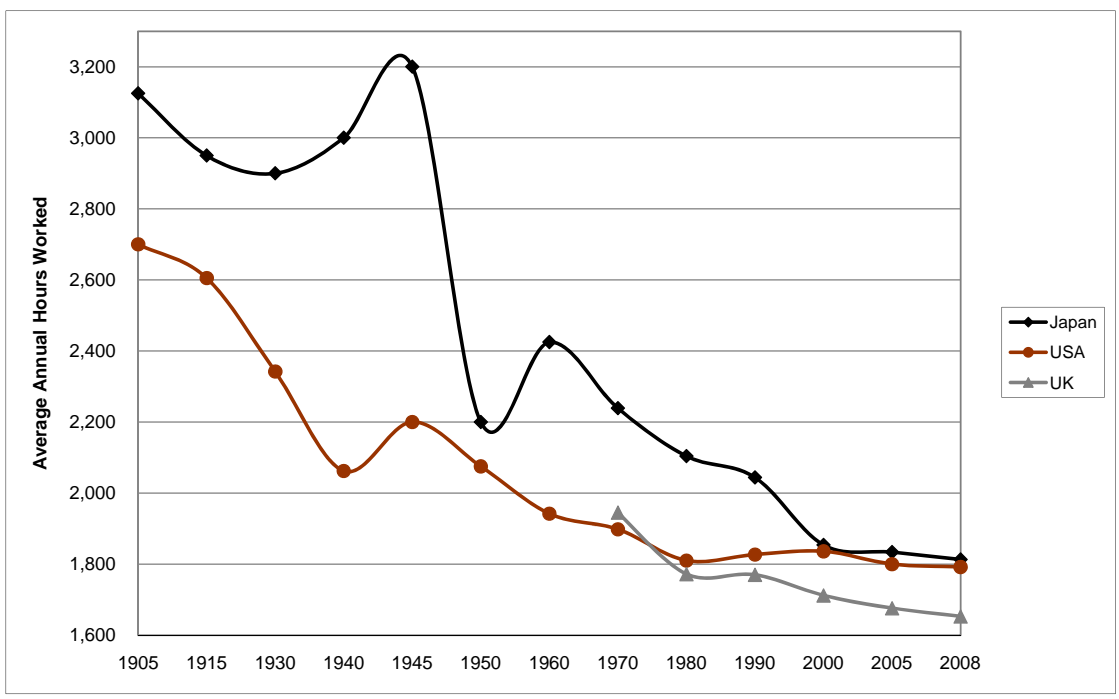

Fig. (1). Average Annual Hours Worked, 1905 to 2008: Japan vs. USA and UK.

Notes: Data are for each person employed. For 1947 on, Japanese data is for establishments with 30 or more employees.

British data were not available prior to 1970. (Sources based upon [19-24]). 
to Japan's Labor Standards Law, first in 1987 and 1998, and through the introduction of the Promotion of Shorter Working Hours Act in 1992 [25, 26]. These policies were further supported by those outlined in Japan's December 1995 National Economic Plan. Combined, these initiatives called for the institution of a five-day, 40-hour work week and the reduction of average annual working hours to 1,800 , to be accomplished by the discouraging of unscheduled overtime, the setting caps on overtime hours worked, and by the encouraging of workers to take all of their paid holidays [21, 25, 27].

By 1999, the Ministry of Labor and the quasigovernment agency JETRO proclaimed that the manufacturing sector and firms with 30 or more employees had implemented the five-day, 40-hour work week, and were on the cusp of achieving the 1,800-hours-per-year work target. The Labor Ministry also stated that it would be the early-2000s before the retail and service sectors, which had numerous firms with fewer than ten employees, would be in compliance $[27,28]$. Despite these claims, between 1999 and 2007, employees in firms with 30 or more worked an average of one full-week a year more than 1,800 hours. This would probably still be the case, if not for the severe worldwide economic slowdown of 2008, which significantly reduced average annual work hours in Japan from 1,850 in 2007 to 1,813 in 2008 [22]. This basically put its firms of 30 or more on par with the USA's total of 1,792 in 2008, but still roughly 160 work hours above the UK. Whether this trend continues, remains to be seen, as a 2008 survey by the Labor Ministry of enterprises of all sizes showed that the average Japanese employee was still laboring an average of 1,968 hours per year. This suggested it would be well into the 2010 s before the 1,800 work year would be truly implemented in Japan [22].

The question then becomes, what has prompted the citizens of Japan, even after their nation was transformed into the world's second largest economy, to consistently work so many more hours per year than their peers in the two largest Anglo-economies/Weber's prototypical cases of the Protestant ethic? While the rebuilding of the country after the devastation of World War II surely played a role in the early post-war era, as various scholars have suggested, at least three more complex embedded factors have been even more influential on Japan's post-war devotion to work: 1) a 'catchup' to the West nationalist ideology that has pervaded the society since the 1868 Meiji Restoration [4, 29-37]; 2) a hegemonic politico-social context which since feudal times has stressed filial piety, including a family-like devotion to master, superior, company, and nation [4, 5, 38-44]; and 3) a segmented internal labor market, which has severely inhibited labor mobility, especially with regard to upward mobility between segments (i.e., workers leaving small-medium enterprises/SME for large firms), for women, in general, and between large firms $[18,39,40,43,45-49]{ }^{2}$

\section{'Catch-Up to the West' Nationalist Ideology}

As Morishima [4], Marshall [30], Samuels [50], and others have described, after the arrival of Admiral Perry's black

${ }^{2}$ Japan's New Small and Medium Enterprise Basic Law defines SME as 300 or fewer employees in manufacturing, 100 or fewer in the wholesale and service sectors, and 50 or fewer in retail [49]. ships in 1853 , Japanese leadership held closely to the idea that the only way in which the country could maintain its economic and political autonomy was to build an economy and a military equal to that of Western nations. In an effort to achieve this, the Meiji Government (1868-1912) embraced and then instilled in the masses a catch-up nationalist ideology that rested upon three principles: 'fukoku kyouhei' rich nation and strong army; 'banpou taiji' - to stand up against all other countries; and 'shokusan kougyou' - with the latter of these connoting more than its literal translation of promoting industrial development, but also calling for the protection of domestic industry from foreign competition [50]. Incorporating Japan's Shinto traditions of filial piety to ancestors and its Shogunal period's devotion to 'daimyo' or feudal lord (to be discussed in more detail in the next section), the Meiji Government was so successful in inculcating this ideology that it was said that even the small children of Japan were speaking about the need to enrich the country and strengthen the military $[29,50]$.

The defeat in World War II and related internal and external prohibitions spelled the end of possessing a strong army. This granted unchallenged supremacy to the goal of a rich nation, and primacy in the post-war reconstruction efforts to the rebuilding of the nation's economy through its manufacturing sector. Initially, this centered on heavy and chemical industries (HCI) supporting the Allied efforts in the Korean War. Thereafter, a switch was made to a full-force export-oriented strategy, producing commercial goods for international markets. While HCI, such as shipbuilding, chemicals, and steel, along with textiles and other labor intensive industries remained important through much of the 1960 s, the focus had shifted by that time to more valueadded and technology-intensive commodities, particularly, automobile production, electronics, and precision machinery [35, 36, 51-61].

Along with major efficiency gains in both process and product, this industrial transformation contributed to the decline in annual hours work from between 2,300 and 2,400 hours in the 1950s and 1960s, to 2,100 in the 1970s and 1980s. Notwithstanding this drop, annual hours worked in Japan remained 300 greater than that of USA and UK workers. In other words, despite surpassing Britain to become the world's second largest economy, Japan's catch-up ideology continued to push its labor to toil many more hours than their Anglo counterparts until the late-1990s, when domestic legal changes restricted such activities.

\section{Hegemony, Filial Piety, and Devotion to Sempai, Com- pany, and Nation}

The second important factor explaining why the Japanese have worked so hard: a hegemonic politico-social context which since ancient times has instilled a strong sense of filial piety in its citizens [38, 41, 62]. According to Gramsci [63], hegemony refers to:

1. The spontaneous consent given by the great masses to the general direction imposed on social life by the dominant fundamental group; ... [and when,] 2. the apparatus of state coercive power...legally enforces discipline on those 
groups who do not 'consent' either actively or passively.

Throughout the early part of its history, and subsequently to a large degree ever since, the native Japanese religion of Shintoism, which has been guided by ancestor worship, has ingrained a sense of loyalty to elder, parent, and family into the psyche of most Japanese citizens. In the Tokugawa Period (1603-1868), filial piety was primarily a straightforward loyalty to the daimyo. As mentioned, during the Meiji Period this branched out into all aspects of life in the government's catch-up nationalist ideology. In the early Showa Period (1926-1989), there was no greater evidence of this commitment to superior and nation than the sacrifices made by kamikaze pilots during World War II. However, in the postwar period, catch-up nationalism and the politico-social hegemony of loyalty were transferred to the Japanese corporate system, especially to firm-employee relations [43]. This new context of trust has ensured a strong work ethic to the present day, even though the nation has become extremely affluent [64].

According to Odaka [41] and Befu [62], in Japanese-style post-war corporatism, which has placed a high priority on group decision-making and devotion to company, trust has been reinforced by the 'sempai-kohai' system, lifetime employment and a seniority-wage structure. That is, in return for complete dedication to company, the worker has gained a pseudo-familial relationship with his colleagues and superiors, and a permanent second home with his firm. Shortly, in the section on labor market segmentation, the way in which lifetime employment and seniority wages have helped to instill loyalty to company, will be discussed. As for the sempai-kohai system, this has referred to the allegiance a junior colleague or staff member (kohai) has shown to his senior colleagues and closest superior (his sempai), and by extension, to his employer $[18,38-40,62,65]$. Nakane [38] claimed that sempai-kohai relations have fully incorporated what she called the Golden Rule of Japanese ethics: No man can serve two masters. She claimed that the transference of this 'golden rule' to the company setting has fostered a kind of closely-knit, 'all-in' or 'all-for-one group' solidarity among colleagues that would have been difficult to cultivate otherwise in contemporary capitalist Japan.

This acculturation process has begun during the initial training period for new employees, through group projects, company retreats, and other activities, in and away from the office/plant. After their training period, new entrants have been placed into groups with peers and sempai, the latter of which also have sempai of their own to which they report. However, as Reed [46] described, this situation has been far from devoid of intra-group competition. He maintained that similar to Anglo-capitalist nations:

The key competition in any Japanese organization has been among individuals ... but this competition has been channeled by rewarding only team players. It has been almost impossible to get ahead in a Japanese organization by stabbing someone in the back. The Japanese social structure has punished mavericks and rewarded team players. [That is to say], Japanese groupism does not come from some natural tendency at birth, but from intensive train-
ing...The Japanese that have gotten together to perform a task have gone to great lengths and have spent an inordinate amount of time producing the proper group dynamics. The effort has been necessary precisely because [groupism] is not natural [sic].

Socialized by their firm that they must compete and collaborate with their peers and sempai in order for the company and themselves to succeed, Japanese labor has committed to working as long as necessary for their firm. In addition to benefiting the firm however, this dichotomy has also provoked the Goffman-like [66] cat and mouse game of workers remaining on the job longer than their peers and their sempai, in order to make a good impression, even if they were not busy. In addition, it has encouraged the practice of 'nomi-nication' - staying out late drinking with colleagues so as to not be excluded from 'real' company business [67]. The latter has inevitably strengthened trust and loyalty among co-workers. Conversely, forgoing such rituals has generally proven costly to the kohai's reputation with his peers and sempai, and to his future prospects with his company $[18,40,45,67]$.

The ultimate results of this situation have been that the kohai's self and self-esteem have become fused with the company's success or failure, and he eventually starts to view his colleagues as his primary group or extended family. In other words, Japanese labor works longer hours than those in the West because they have been conditioned to believe that it was morally the proper thing to do. In this way, they have not been that much different from Weber's Calvinists, who viewed their calling to work as proof of their devotion to God, and imperative to their success in the after-life.

\section{Segmented Labor Market that has Promoted Loyalty but Inhibited Labor Mobility}

The third embedded factor that has induced Japanese labor to work long hours for their company has been a segmented internal labor market. This has promoted both a strong sense of loyalty between worker and firm, and has greatly inhibited worker employment mobility between SME and large firms, and between one large firm and another. The result has been that workers toil long hours out of a sense of self-preservation, due to an actual and perceived lack of job alternatives $[18,39,40,45,46,48]$. That is, they will do anything to avoid losing their jobs, fearing that they will be unable to secure another position, and even if they can, it will be at a lower pay, rank, and status.

The three pillars of Japan's segmented labor market system have been profit-sharing bonuses, seniority-wages, and lifetime/career employment, all of which have been provided by most large firms and by some SME to their full-time employees $[18,43,68]$. Profit sharing has induced long working hours in the post-war period by again tightly linking individual rewards to company success. During the 1970s and 1980s, employees of large firms typically received nearly one-third of their total compensation through semi-annual bonuses, disbursed during the traditional mid-year and yearend holiday seasons, with some very successful firms providing bonuses as high as a full year's basic pay. Since the 
1990s, workers have received an average of about two month's basic pay in bonuses $[69,70]$.

According to Reed [46] and Fukuyama [71], Japanese companies have made bonuses derived from company profits a major part of compensation in an effort to ensure individual employee commitment to the firm. Or as Matsumoto [43] stated, "viewed from the employees' standpoint, they know that if the company were to prosper they would benefit from higher salaries, promotions, improved health and welfare benefits, as well as socially, from the company's higher prestige."

The bonus system has provided several other advantages to companies and nation. For example, it has allowed firms to keep base salaries down and to invest the deferred funds in $\mathrm{R} \& \mathrm{D}$ or productive activities, both of which have benefited the firm in the long-term [70]. This has enabled large companies to keep on labor and/or to transfer them to a new product division during down-times, which has served to maintain worker trust and to further encourage a greater sense of employee responsibility to company [43, 46, 71]. According to Abegglen [70], one way in which the bonus system has benefited the nation has been that it has promoted a high-rate of household savings (to be discussed later), a large proportion of which has been deposited in governmentrun postal savings accounts. These monies have then been utilized to fund public infrastructure projects and to provide grants and loans promoting corporate and national economic growth $[33,44,57,70]$. By the same token, ten months of household austerity has created added pressure on employees to work harder/longer for their company, in order to ensure that their company prospered enough for them to receive their semi-annual bonuses.

In reference to seniority-wages (compensation based on years of service to firm), one manner in which it has promoted worker loyalty has been the previously mentioned sempai-kohai relations. In such a context, it would belie convention for Japanese firms to pay their senior staff less than their junior employees. As outlined, this hierarchy then has ensured that kohai would work hard without complaint, in order to receive a promotion. Related to this, since postwar Japanese firms also have focused on training their workers to become generalists rather than narrowly-trained specialists, they have valued tacit knowledge gained from job experience over explicit knowledge learned from books/merely educational attainment $[72,73]$. To instill such knowledge, firms have regularly rotated their workers among job responsibilities and corporate locations. As such, becoming a valuable team member has required a lengthy apprenticeship. With worker compensation and promotion evaluations based on length of and meritorious service to a given firm, with the latter generally defined as a total commitment to company, this situation has created an abundance of employees willing to work long hours for the firm $[34,43,47$, 74].

As for lifetime employment, it would seem fairly evident as to why it would have fostered employee loyalty, trust, and a propensity to work long hours: it has translated to job security. There have been countless tales of company men who devoted their lives to their firm, both in the East and in the West. However, as will be discussed shortly, there has been much more to its impact on work hours than that. According to Fukuyama [71], career employment, from the time of hire until retirement age, has created similar extra-kin relationships between Japanese companies and their workers as the high standard of outside the family trust that Weber found in the American Calvinists he observed. Weber [12] believed that such relations were necessary for the development of capitalism.

Fukuyama [71] maintained that one outgrowth of this mutual trust in Japan was that management and factory foreman have felt a much greater degree of responsibility for their workers than supervisors in Anglo-capitalist countries, as if they were their own children. This, he said was illustrated in the implied promise by management that the firm would keep on its loyal employees, either in their present job or with a company affiliate, no matter the economic conditions; Toyota has kept this promise even in the USA during the current economic crisis. As Matsumoto [43] wrote, only in extreme situations, such as bankruptcy, has this not been the case. In turn, workers have naturally repaid their firm's fatherly protection with a willingness to work much longer hours per day than the compatriots in the West $[43,71]$.

However, while much has been in the scholarly literature in regard to Japan's lifetime-employment system, trust, and groupism, as Ono [68] explained, depending upon how it was operationally defined, over the past two decades, only between 20 and $35 \%$ of the Japanese work-force actually have had lifetime employment. So the question then is, with only one-third or less of workers having career employment, how could this factor have inhibited upward employment mobility or discouraged transfers from one large firm to another?

One possible reason is that a much greater proportion of the Japanese public has continually and overwhelming valued lifetime employment than actually has had it. Surveys by the Japan Institute for Labor Policy and Training (JILPT) [74-76] over the past 15 years have consistently found that in excess of 70 percent of Japanese workers favored retaining lifetime employment, while another two-thirds supported keeping the seniority-wage system. Meanwhile, JILPT [74, 75] surveys conducted between 2003 and 2007 also revealed that more than two-thirds of Japanese companies still believed that lifetime employment should be maintained for as many employees as possible, and less than 28 percent favored eliminating seniority-based pay. Next, as Matsumoto [43] noted, further evidence that lifetime employment and seniority wages have remained highly-valued in Japan has been the fact that both have represented merely unwritten agreements between management and labor. Neither has been formally inserted into contracts between companies and employees, but has been nothing more than institutional practices that have become accepted societal norms [43, 64].

In other words, it could be argued that, despite the relatively small proportion of workers that have had lifetime employment, Japanese society has continued to highly value these tenets, and thereby, worker loyalty to firm. This belief system has then served to greatly influence the decisions made by workers related to firm selections and job separations. According to Matsumoto [43] and current JILPT surveys [74], such a context has pressed workers to remain with their firms no matter the job conditions. It has done so by stigmatizing those workers who have changed companies as 
incapable of holding a job, or unable to get along with others. Changing firms has also typically led to such workers suffering falling wages and position rank, as well as a drop in the social status of their company. One reason for the latter has been that work experience with their prior firm generally has not been considered of value to most other firms, and therefore, required them, no matter their age, to start over again from the bottom rung of the seniority ladder [43]. Taking a less critical approach, Nakane [38] also claimed that workers have been dissuaded from changing companies by the fact that a transfer would result in them losing the important social capital they have built up over the years with their colleagues and supervisors from their original firm.

This situation, along with other social forces, such as a national ideology stressing women should raise their own children and thereby, pressuring them to quit their jobs upon marriage or when they have had children, has especially limited the upward labor mobility of women. Although Japanese law has prohibited gender-based employment discrimination since the mid-1980s, in practice, the lifetime employment and senior-wage system has still allowed firms to favor men over women. The result has been that more than 40 percent of all women in the Japanese work-force have remained nonregular workers (part-timers or contract workers) without full benefits, even if they have worked in excess of forty hours per week; Japan's percentage was twice that of the USA $[18,69]$.

The old Japanese adage, 'deru kui wa utareru,' the proverbial 'stake that sticks up gets hammered down,' seems applicable here, as well. Japanese people have been taught to avoid open confrontation and to not stick out in the crowd [67]. Since only one-third of the work-force has had lifetime employment, forsaking such a sacred privilege to change companies has constituted a violation of a precious social mores. Not only has it connoted a selfish individualist attitude that showed a lack of respect for the group, it also has evoked the feeling, especially among those without career employment that 'your behavior is ruining it for all of us.'

By the same token, Matsumoto reminded us, within a context of such accepted mores, there also has been a great deal of societal pressure discouraging managers from layingoff their employees. He stated that Japanese corporations have always sought to avoid dismissing employees, "and when large-scale dismissals [have been] forced upon a corporation, the company's managers often have become the targets of social criticisms, and considered somewhat irresponsible" for their actions [43]. Such a 'loss of face' has then sometimes prompted not only the resignations, but in some cases, even the suicide of top-management, mimicking the ritual of 'harakiri' practiced by fallen feudal lords and their loyal samurai. In other words, Japanese society has expected their company masters to live up to the same high degree of loyalty that it has demanded of labor. These sentiments were institutionalized even further in November 2007, when the Japanese government passed its Labor Contract Act Law, which made it illegal to fire a contract-worker (i.e., without lifetime employment), without clearly defined objective grounds for such a dismissal.

Finally, while lifetime employment and seniority wages have surely fostered trust between company and worker, they, along with the Japanese corporate system's strict status hierarchy, which has heavily favored large export-oriented firms, have also led to the development of a rigid, segmented labor market. The result has been that job mobility has been greatly inhibited, even when switching firms would have benefited the worker in the long-term. As many studies have shown, during the post-war era, job separation rates in Japan have been significantly lower than those in the West [18, 33, 46, 47, 68, 69]. Additionally, based upon the Organization of Economic for Co-operation and Development (OECD) definition of low job mobility-i.e., having a small percentage of workers in short-lasting jobs with tenure of less than one year, and a large percentage of workers in long-term jobs, with tenure over 20 years- since the 1970s, Japanese labor has had the lowest or among the lowest job mobility rate among OECD nations; the USA has had the highest rates $[47,68,77,78]$.

This suggests that while trust between company and worker has been instrumental in encouraging Japanese labor to work long hours, worker pragmatism has been equally important. As Matsumoto [43] argued:

The real nature of the allegiance a Japanese employee has felt toward his company, or what has been called his feeling of belonging, has derived from [actual] objective conditions. It has been nothing more than employees being in a situation where they have been forced into sharing corporate risk and taking on such feelings as an extension of their personal best interests... The difference in the attitude of a worker and the ties that bind him to company in Europe or the USA compared with those in Japan has arisen out of differences in objective conditions...[and] not necessary differences in national mentalities, represented by such concepts as Western individualism or Japanese group mentality [sic].

Or, as Reed [46] claimed, while it seems that the Japanese prefer employment security over merit-based pay and job mobility, the real difference between Japan and the West has had more to do with the options available to them. Within such an embedded labor context, Japanese workers have done whatever necessary not to lose their jobs, including: not taking vacation and sick days; foregoing their marital and parental responsibilities by accepting multi-year transfers to locales far away from their homes, or by regularly staying out late drinking with their colleagues; and, working themselves sick or to death, as recent studies citing the continued rise in 'karoshi' (literally, death from overwork), have illustrated $[18,64,79,80]$. They have done so because they have known that if they lose or leave their present job, they either will be unable to find another position or have to work for lower pay, at a lower rank, and for a firm with much lower societal prestige. All of which would lead to a loss in social status for them and their families, and thereby, a loss in their self-esteem.

\section{HIGH SAVINGS RATES: INSTITUTIONALIZED AS- CETICISM IN JAPAN}

Another prime example of how the Japanese ethic has mirrored Weber's Protestant Ethic has been the Japanese 
inclination to save. In the post-war period especially, Japanese asceticism has been most evident in its household and national savings rates, which have far exceeded those of almost all other advanced industrial nations, especially the two largest Anglo-nations, the USA and UK [32-34, 44, 70, 8184].

Due to the lack of available comparable data, it was only possible to compare Japan's savings rates to those in the USA and UK since 1960. Moreover, due to periodic changes in their own methodologies, the national percentages published by OECD for Gross National Savings (GNSR) as a percent of nominal Gross Domestic Product (GDP), and for Household Savings Rates (HHSR) as a percent of disposable household income (DHHI), have undergone frequent revisions. Nevertheless, no matter which year OECD reference book was consulted, between 1960 and 1999, Japan's GNSR and HHSR were consistently 1.5 to 2.5 times higher than those for the two largest Anglo-capitalist economies, the USA and the UK. For example, as shown in Fig. (2), according to the OECD, between 1960 and 1979, Japan's GNSR ranged between 31.2 and 40.2 percent. Thereafter, it hovered around 30 percent through the 1980 s and 1990 s, and stood at 27.0 percent in 2007. Overall, it ranged from 25.2 to 33.6 percent between 1980 and 2007. By comparison, the USA's and UK's GNSR were usually about half of the Japanese figure, both ranging from 15.7 and 21.7 percent prior to 1980, and between 14.0 and 19.0 percent after 1980. In 2007, the USA's GNSR percentage stood at 13.7 percent, while the UK's GNSR was 15.6 percent [85-88].

As shown in Fig. (3), a similar pattern existed for HHSR, at least between 1969 and 1979. According to the OECD, during this period, when Japan's Net HHSR ranged from between 13.5 and 24.4 percent, it was generally twice that of both Anglo economies; the USA's Net HHSR percentage ranged between 8.4 and 10.6 percent and the UK's Gross HHSR was between 4.7 and 11.8 percent. Although declining, Japan's Net HHSR remained around 14 percent or higher for most of the 1980s, and in double-digits between 1980 and 1999, ranging from between 10.1 and 18.4 percent.
In contrast, between 1980 and 1999, the USA's Net HHSR percentage was below 10 percent in 16 out of 20 years, and ranged from between 2.4 and 11.2 percent. Meanwhile, the UK's Gross HHSR was consistently in single digits, ranging from 4.1 to 13.2 percent during this period $[89,90]$.

It must be noted here that HHSR the OECD reported were actually skewed in favor of the Anglo nations, as Japan's OECD statistic represented only its households' savings relative to DHHI, while the two other countries' figures included the savings of non-profit organizations. Moreover, the UK's HHSR reported by OECD was inflated by the fact that it was one of six European countries which reported 'gross' household savings as opposed to 'net' household savings; this means the UK figure included the consumption of fixed capital by households and unincorporated businesses [87]. In sum, the disparity between Japan's HHSR with the Anglo-nations was actually even higher than OECD figures demonstrated.

The magnitude of this difference from the 1970s to the 1990s was probably best described by Fingleton [44], when he powerfully wrote that in 1993, Japan's HHSR of $\$ 819$ billion was 11 times that of the USA ( $\$ 75$ billion), and represented 56 percent of the entire industrial world's savings, as compared with just 5 percent for the USA. As posed by Fingleton, these dramatic figures provoked one straightforward question: Why have the Japanese been super-savers?

\section{Japan's Super-Savers}

Morishima [4] claimed that frugality has long been a foundation tenet of Japanese-style Confucianism. He then maintained, however, that its importance was substantially raised during the late- $19^{\text {th }}$ Century, after the Meiji Government issued its imperial injunction to the armed forces, which emphasized it, along with loyalty, ceremony, faith, and bravery, as the most important virtues to be observed by the military and all segments of Japanese society. Fingleton [44] himself suggested that by the $19^{\text {th }}$ Century the Japanese were already regarded by the Europeans as a nation of spendthrifts. On the other hand, according to Yamamoto [91]

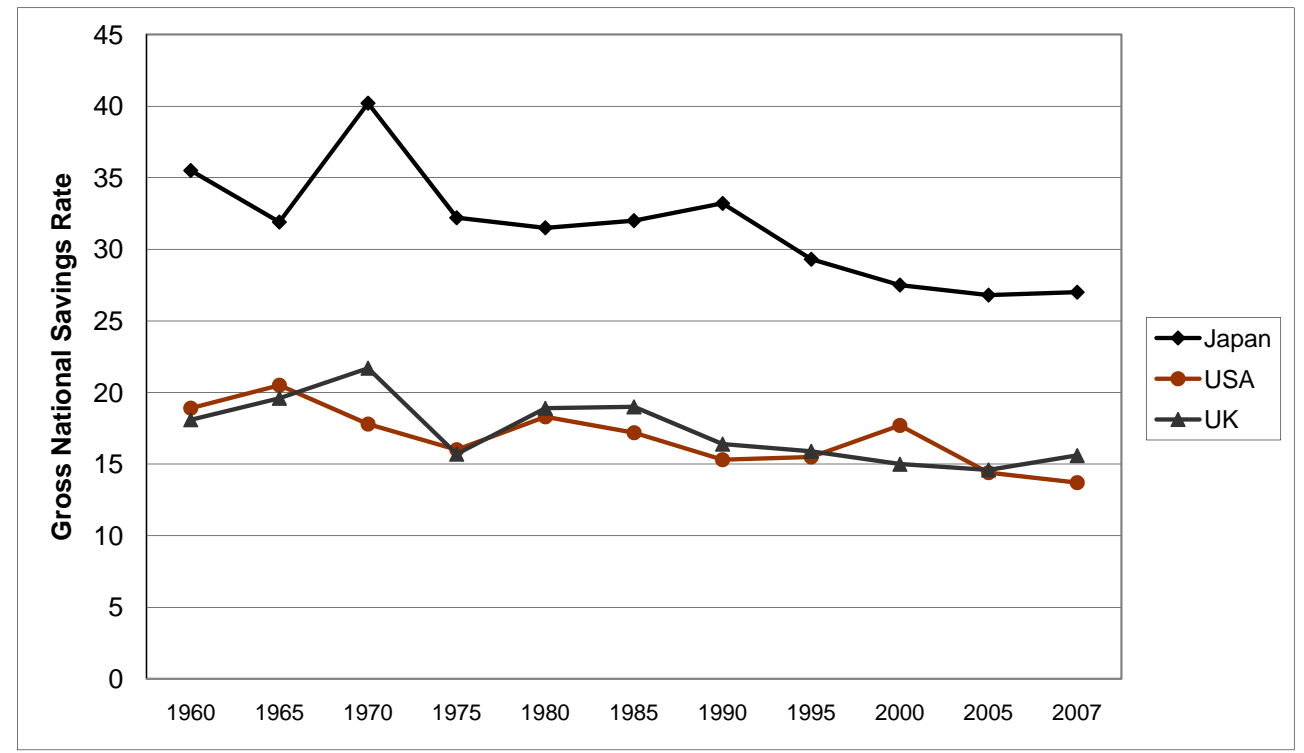

Fig. (2). Gross National Savings Rate 1960-2007: Japan vs. USA and UK.

Notes: The Gross National Savings Rate is the national savings as a Percentage of Gross Domestic Product. (Sources: based upon [85-88]). 


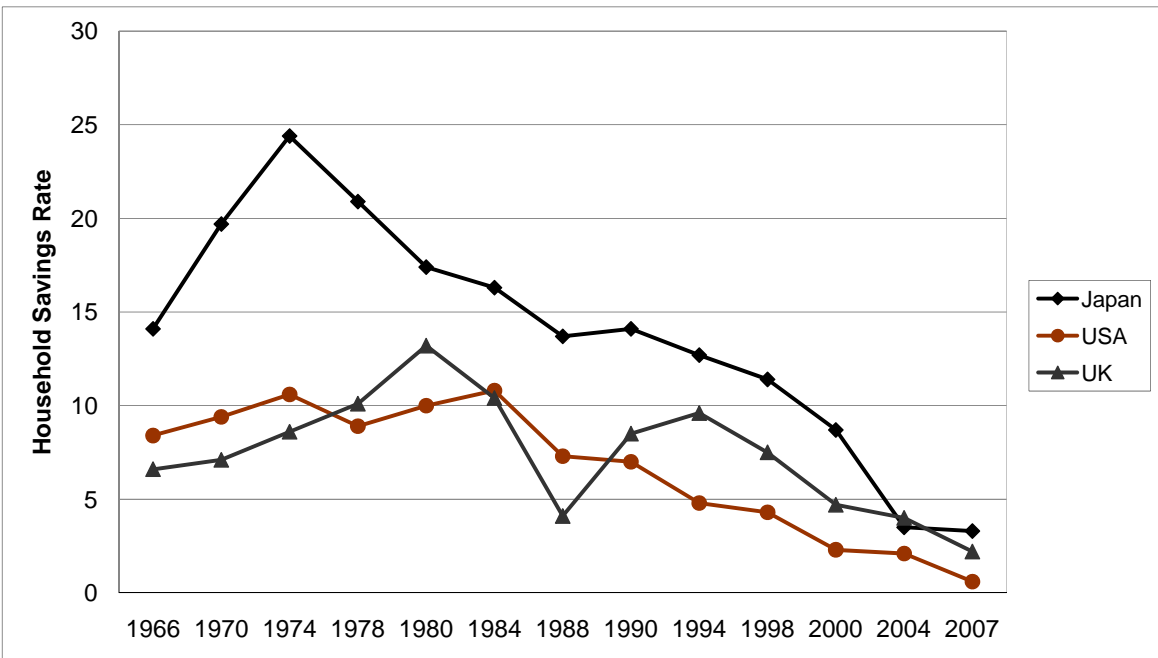

Fig. (3). Household Savings Rate 1966-2007: Japan vs. USA and UK.

Notes: Since the OECD regularly re-adjusts past figures to inflation, in some years there are slight disparities from past $O E C D$ published figures.

Net Household Savings Rate is equivalent to net savings as a percentage of disposable household income. The UK is one of six European countries which reports Gross National Savings rather than net savings, therefore, its figure is somewhat overrepresented in this chart. Conversely, since Japan reports only household savings to the OECD, and does not include non-profit organizations, its figures are actually underrepresented here (Sources: Based upon [89, 90)]).

and Bellah [92], frugality became a significant part of Japanese ethos in the late- $18^{\text {th }}$ Century, when the teachings of merchant turned philosopher, Baigan Ishida, became popular among Osaka, Kyoto, and Edo (now Tokyo) businessmen, samurai, and townspeople. ${ }^{3}$ These scholars also contended that the Ishida school of ethics, which came to be known as Sekimon Shingaku (a blend of Shintoism, Confucianism, and Buddhism), and whose principles viewed work and asceticism as a Zen calling, had played an influential role in the development of a spirit of capitalism in Japan.

While these claims of a traditional Shinto-ConfucianBuddist ethic grounded in frugality warrant consideration, Japan's GNSR and HHSR only began to consistently rise after the end of the Allied Occupation in 1952 [44]. Prior to that, they fluctuated dramatically up and down depending on contextual circumstances. For example, prior to the $1910 \mathrm{~s}$, the country was not affluent enough for either its government or masses to save a substantial amount of their income. Savings rates then significantly rose between the mid-1910s and the early-1920s, then fell noticeably between 1923 and 1932, before increasing dramatically in the 1930s [84, 92]. The two periods of growth coincided with the buildups to World War I and II, when domestic consumption was suppressed by military demand for raw materials [84, 93]. The devastation of the World War II then led to a substantially fall in all savings rates during the 1940s, before the increases of the 1950s [44, 84, 94]. As a result of these trends, most scholars have suggested that post-war changes to embedded structures have had more to do with Japan's high post-war HHSR than any deep-seated cultural propensity to save [32, $33,40,44,55,57,84,95,96]$.

${ }^{3}$ Bellah said that Jodo Shinshu Buddhism, (True Pure Land School), founded by Shinran Shonin in 1175, and currently the most widespread Buddhist sect in Japan, also stressed hard work and asceticism. Weber thought otherwise and stressed how devout Buddhist monks shunned work.
Combined, this perspective has claimed that the following institutional factors better helped explain Japan's high savings rate: 1) a relatively 'small' government country, which has spent a much lower percentage of its national income, as compared with the USA and UK, especially for national defense; 2) the aforementioned worker compensation, which has deferred salary through its semi-annual bonuses and thereby, has forced workers to be frugal; 3) an under financed public social security system, which has not provided large enough pensions for retirees; and 4) national government policies that have severely suppressed consumption. Among these, the last item requires the most detailed explanation.

\section{National Government Policies Severely Suppress Con- sumption}

According to Fingleton [44], the government has suppressed household consumption in two important ways. First, its strict regulations on consumer credit have basically maintained Japan as a cash payment, rather than a check writing and credit-oriented, economy. Second, in an effort to protect Japanese manufacturers, the government enacted high tariffs and trade barriers to discourage consumer and firm purchases of import products. Similarly, Johnson [55, 95] and Huber [57] pointed out that, in order to keep the prices of exports of strategic industries abroad low, domestic prices for related products were kept artificially high. This also served to expand the global market shares of Japanese firms, and to maintain it as a producer, rather than a consumer-oriented, economy. In other words, the cost of living in Japan has been artificially inflated, which has forced its citizens to save and pay more for daily necessities and bigticket items than have residents of nation's major export markets, such as the USA. 
As a result of such structural impediments to consumption, Fingleton [44] argued that even during the country's severe economic slowdown of the early-1990s, when savings in theory was supposed to shrink dramatically, Japan's HHSR remained strong. However, this trend did not continue into the 1990s and 2000s. Rather, Japan's HHSR have declined dramatically since 1991. Between 1991 and 1999, Japan's HHSR fell from 15.3 percent to 10.1 percent (Fig. 3). Thereafter, they dropped precipitously to only 3.3 percent in 2007 [90].

Certainly, the bursting of the Japanese land and stock bubble and the ensuing economic malaise played an important role in the reduction in HHSR and GNSR during the 1990s [7, 96]. Several other non-cultural factors have further compounded their declines ever since. Among them were: 1) rising trade barriers in the West (import quotas, domestic content laws, and tariffs), which were intended to force Japan to further open its own economy to Western imports and to expand its foreign direct investment in the West; 2) the rapid appreciation of the Japanese Yen ('endaka' in Japanese) against foreign currencies during the early-1990s, which cut heavily into the profits of export firms. For example, the Yen rose from 157 to the US Dollar in April 1990 to an all-time high of 79 in April 1995, before a series of currency interventions by the Bank of Japan caused its value to fall to the 120s during 1997; and 3) Japanese government's policies, particularly during the Koizumi Administration (2001-2006), which further liberalized the nation's economy $[97,98] .{ }^{4}$ One outcome of these three events was the shift in a significant amount Japanese manufacturing production overseas, not only to North America and Europe, but also to China, in order to circumvent Western trade barriers against Japan. This led not only to a rising trade deficit with China, but rising unemployment, as it contributed a great deal to the loss of more than four million manufacturing jobs in Japan between 1991 and 2006, of which 1.03 million were lost between 2001 and 2006 [98-100].

Global production shifts, however, also induced sharp declines in HHSR in nearly half of the OECD's 27 so-called high-income nations since 1991. In the case of the two largest Anglo-economies, HHSR in the USA contracted from 7.3 in 1991 to 2.4 percent in 1999 , and then to just 0.6 percent in 2007. Meanwhile, it fell from 10.8 to 5.2 and then to 2.2 percent respectively, in the UK, during this period [90]. So while Japan's HHSR may have moved more toward those in the USA and UK, domestic policy changes and external pressures on Japan and on Japanese households have been most responsible for this occurrence. The post-war embedded institutional structures, which provoked high savings through the early-1990s, have remained in place in Japan, and have continued to provoke a Weberian-like asceticism among its households and firms. The fact that the nation's GSNR of 27.0 percent has remained almost twice that of the two largest Anglo economies, clearly attests to this.

While embedded structures have induced asceticism, as the next section chronicles, a third key element mirroring

\footnotetext{
${ }^{4}$ The Yen fell to between roughly 120 and 140 from 1997 to 2000. It then was in the 105 to 120 range between 2000 and September 2008, before again rapidly appreciating to less than 100 Yen per US Dollar for most of 2009. It began 2010 at around 92 . The Yen rose from 260 Yen to One British Pound to 132 during the same period, and stood at around 150 to the Sterling to start 2010 [98]
}

Weber's Protestant Ethic and spurring the rise of Japanese capitalism has been its rich history of entrepreneurship, a tradition which dates back more than four centuries.

\section{A 400 YEAR-PLUS HISTORY OF PROFIT-DRIVEN ENTREPRENEURS IN JAPAN}

Whereas a great deal has been written about the connection between long working hours and high savings rates and Japan's post-war economic miracle, much less has been written about the role its entrepreneurs have played in this success. Perhaps, this has been as a result of the constant focus in both the English and Japanese language scholarly literature on the importance of collectivism in Japan. However, individualistic, profit-oriented private entrepreneurs, Reed's untrained mavericks, who have been willing to rise up against the establishment and risk being hammered down, have also been vital to the emergence and success of capitalism in Japan.

As discussed earlier, Weber believed that as a Confucian society, Japan was too firmly grounded in taboo, traditional authority, and substantive rationality to foster economic individualism among its citizens. Moreover, he argued that since Japan continued to view merchants as of the lowest social status, even among the 'heimin' or commoners (farmers, artisan, and merchants), its belief system prevented it from developing a rational money economy. Combined, these factors inhibited it from cultivating the entrepreneurial spirit necessary to develop capitalism [13, 17]. However, as mentioned, a money economy replaced bartering in Japan centuries before Weber, by most accounts in the early- $17^{\text {th }}$ Century [101-104]. ${ }^{5}$

According to historians, the government first attempted, albeit unsuccessfully, to promote a money economy, in the eighth century. Then, in the late- $12^{\text {th }}$ Century, the circulation of money spread rapidly, when it was written that there was "a strange sickness going around the country...called the money disease" [101]. By the $15^{\text {th }}$ Century, copper coins imported from China were regularly used in commercial centers, such as Osaka and Sakai, for overseas trade. This was followed by the establishment of the currency 'Ryo' in 1601 , which was measured in coins called 'koban' and was equivalent to the US Dollar when under the gold standard. Thereafter, in 1615, paper money appeared in the form of notes issued by merchants [101-104].

While it was certainly possible that Weber was simply unaware of these facts, he certainly should have been aware of the Yen being clearly established as the legal currency of commerce in Japan in 1871, nearly 35 years prior to his publishing of the Protestant Ethic, and 45 years prior to his publishing of the articles which would become known as the Religions of Asia. He also should have known that, at the time of his manuscripts in the early $20^{\text {th }}$ Century, Japan had not only established a money economy, but also had transformed itself into an expanding imperial empire, with the highest standard of living and savings rate in Asia, and with

\footnotetext{
${ }^{5}$ Sansom claimed that mercantilism and a money economy first flourished in Japan as early as the $12^{\text {th }}$ Century, but were later terminated by the feudal leaders [101]. Meyer suggested that an early stage of capitalism was alive and well in Japan perhaps as long ago as the $14^{\text {th }}$ or $15^{\text {th }}$ Century, when Japanese merchant traders were already dominating Chinese shipping and commercial lanes [102].
} 
the most advanced military, industry, and economy among Confucian nations $[83,92,105-110] .{ }^{6}$

Finally, while Weber remained focused on Confucianism, feudalism, and the samurai warriors of Edo, what he overlooked was the vibrant merchant class that had emerged and had been accepted as legitimate in Japan, long prior to his writings. As Meyer [102] wrote, by the mid- $19^{\text {th }}$ Century, entrepreneurial skills were well developed in the country, and "in every village there was at least one wealthy farming family" which had profitable auxiliary businesses on the side. However, these merchants were not just part of a new wave of entrepreneurialism. Rather, many of them were descendants of a rich tradition of entrepreneurship dating back to the $17^{\text {th }}$ Century, if not several centuries before [101-103, $111]^{7}$.

In other words, at the forefront of the origins of Japan's capitalist development were private firms, most of which were established by profit-seeking commoners, some from very poor families, others from traditional merchant families, "who rose to become leading entrepreneurs through their willingness to work days without sleep" [105]. It was these same family firms which spawned many of the large banks, trading companies, and industrial conglomerates which dominated Japan during Weber's time, and which would become the loci of the nation's post-World War I and postWorld War II economic and industrial growth [4, 91, 105, $112,113]$. Perhaps the best examples of Japan's historic tradition of entrepreneurship were the merchants of the feudal states ('kuni') of Ise, Omi, Izumi, and Settsu, which now encompass parts or all of Mie, Shiga, Osaka, and Hyogo Prefectures [101, 103, 114]. ${ }^{8}$ During the Tokugawa Period (1603-1868), the merchants of Ise and Omi became so numerous and well renowned in Edo for their salesmanship, ability to accumulate wealth, frugality, and general love of money that envious rivals in that city began referring to them as the 'Ise Kojiki' (the Misers or Beggars of Ise), and the 'Omi Dorobou' (the robbers of Omi) [103]. The markets of Izumi and Settsu, centered on Sakai and Osaka, date back to the $14^{\text {th }}$ and $15^{\text {th }}$ Centuries, respectively. The area was so renowned for its commercial activities that it was frequently referred to as either the 'Manchester of the Orient' or the 'Manchester of the Far East,' [115-118].

\section{The Merchants of Ise}

Ise merchants first became known in the middle of the $16^{\text {th }}$ Century, for selling cotton throughout Japan, when that crop was first introduced to the nation. Since the cotton they imported was of such high quality, Ise merchants accumulated wealth by selling it to both well-to-do citizens and to kimono makers. The Town of Matsusaka became an important market center for Ise trade, as it was within proximity of a busy port on Ise Bay, and served as a resting point for sailors, traveling merchants, and others making pilgrimages to

${ }^{6}$ It conquests over the China and the Russia in the Sino-Japanese (1894-95) and RussoJapanese (1904-05) Wars, had brought Taiwan, Korea, and southern Manchuria under its umbrella. Twenty years earlier, in 1872, it also had annexed the Ryukyus (Okinawa) from China $[102,110]$.

${ }^{7}$ This provokes the question some, such as Giddens [111] have asked, as to whether or not capitalism and feudalism can be simultaneously present in a given society. He called such events, time-space edges.

${ }^{8}$ Other good examples included the merchants of Owari (Nagoya), Mikawa (now eastern Aichi Prefecture), and in Toto'umi (now western Shizuoka Prefecture) [103, 114].
Ise Jingu, then, and now, the most sacred Shinto shrine in all of Japan [119]. ${ }^{9}$

By the late- $17^{\text {th }}$ Century, so many Ise merchants had set up drapery and related shops in the Shogunal capital of Edo, that the city became known for three things: 'Iseya' (shops called Ise's/from Ise), 'Inari' (shrines), and dog droppings. Several of today's retail and trade giants also began their operations in Ise. For example, AEON, which was Japan's most profitable general merchandise chain during the early2000s, was established as the kimono fabrics and accessories shop, Shinoharaya, in 1758, in what is now the City of Yokkaichi [120].

Yet, the foremost example of Ise's entrepreneurial spirit of capitalism has been Mitsui, whose commercial empire can be traced back at least three centuries to Sokubei Takatoshi Mitsui. Although historical accounts vary, legend has it that Sokubei was born in Omi, but later settled in Matsusaka, Ise. This meant he was socialized in the two areas renowned for having the shrewdest merchants in Japan. It was in Matsusaka in 1616 that Sokubei denounced his samurai rank and dedicated himself to commerce [113, 119, 121]. This was a monumental decision, because at the time, as Roberts [119] noted:

Officially, commerce was considered a parasitic occupation, and the 'chonin' (the townspeople, including merchants), occupied a social rank just one step above the 'eta' (the outcastes), who were not even classified as human beings. Sumptuary laws prohibited the chonin from wearing fine clothing, using certain forms of speech, or living in districts of the city that were inhabited by samurai [sic].

Nonetheless, Sokubei was not alone in his decision. By the early- $17^{\text {th }}$ Century, as the ceaseless warfare of the previous decades was subsiding, and a money economy was replacing the bartering trade, thousands of samurai were trading in their swords for the abacus [113]. As a result, despite formal discrimination, the nation's merchant class expanded rapidly, and became tolerated and eventually accepted by the feudal leadership, at least 200 years before Weber's theses [91, 103, 119, 121].

Sokubei began his entrepreneurial career by opening a brewery in Matsusaka called 'Echigo Dono no Sakaya' (Lord Echigo's Sake Shop) [113]. He made enough money in this and his other business ventures to get married and father 12 children $[113,121]$. When he died in 1633, his widow, Shuho, herself the daughter of a successful merchant, sent their sons to apprentice with local commercial establishments. When their eldest son, Toshitsugu, was fully trained, she dispatched him to Edo to open a drapery shop, which he called Echigoya (Echigo's) [119]. A few years later, she sent her younger son, then 14-year old Takatoshi, to assist his brother, where they opened a second shop. This was an astute entrepreneurial decision for two reasons. First, it was shrewd because, thanks to the alternate residence proclamation made by the Shogun Iemitsu Tokugawa in 1635 (sankin kotai), which required all of the country's feudal lords to spend half the year living outside of their home

\footnotetext{
${ }^{9}$ Ise Jingu is currently within the boundaries of Ise City.
} 
fiefs and in the Shogunal capital, Edo was on its way to becoming Japan's most vibrant marketplace [122]. Second, it was wise because Takatoshi would become the driving force behind the creation of the Mitsui Empire.

When the elder Toshitsugu left to open another shop in the Imperial Capital of Kyoto, Takatoshi took charge of the Edo stores. However, after 14 years in Edo (1636-1650), and after saving 1,500 ryo, an enormous sum equivalent to 750 pounds sterling silver, the death of another brother forced him to close the Edo stores and return to Matsusaka, in order to help his aging mother run the family businesses [119]. Bored with these endeavors, Takatoshi decided to expand into banking. This included lending money and settling accounts for other merchants, as well as collecting tax payments for the Tokugawa Shogunate (or Bakufu in Japanese). The performance of the latter was limited to a handful of highly trusted financiers, and involved collecting taxes paid to the Bakufu, principally in rice, which was then sold on the market in Osaka [123].

As Roberts [119] explained, exchange houses, such as Mitsui profited handsomely from these operations, not from collecting transaction fees from the government, but from being allowed to take several months to settle these tax claims with the Bakufu. In the meantime, through "various manipulations familiar to experienced commodities speculators, the merchants caused the rice prices to fluctuate widely, and with foreknowledge of price changes, managed to turn neat profits both ways [from buying and selling], in addition to the high rates of interest" they earned from lending money to farmers and other merchants.

Takatoshi passed his operations on to his six sons. Central to his legacy was Mitsui Bank, "which began operating in 1683, a decade before the Bank of England was founded" [119]. Mitsui Bank, which was officially recognized as a private bank by the Japanese government in 1876, under the revised Banking Act of 1872, dominated the Japanese banking sector from the Meiji Era to the mid-1900s [124]. In 2001, the bank, then known as Sakura Bank, was merged with the large Osaka-based Sumitomo Bank, part of another historical conglomerate to be discussed, to form the Sumitomo Mitsui Banking Corporation (SMBC). As of March 31, 2009 , SMBC had assets of 107.48 trillion yen or $\$ 1.19$ trillion [125].

As for the family's retail clothing operations, in 1673, Takatoshi moved to Kyoto and opened a fabrics store, which later sold fashionable garments and silks. He then opened a second store, also named Echigoya, in the high-class Honcho-dori market area of Edo's Nihombashi district. However, instead of basing his business upon the selling of kimono and other high-end products for the upper class, he sold cloth to commoners. As Sansom [103] described:

Mitsui sold cotton goods in great variety at fixed prices for cash, a departure from the common practice of [bartering]. They aimed at attracting customers in great numbers, advertised freely, and were ready to sell in small quantities to poor purchasers. Competing with the Echigoya were the Iseya, which opened branches in every ward of the city.
"As Echigoya flourished, Takatoshi set up branch establishments in Kyoto and Osaka, preceding by nearly two hundred years, the chain store system popularized by the Atlantic \& Pacific Tea Company (A\&P) in 1860" [119]. By 1700, the Nihombashi shop was Japan's largest store, and would ascend to become the showcase operations for the retailer Mitsukoshi, long the nation's largest department store chain, and the nation's second largest at the time of its 2008 merger with Isetan. Interestingly, the latter was a Tokyo-based major retailer whose founder, Kosuge Tanji, also was a descendant of Ise, and who began his operations in 1883 as the kimono store Iseya Tanji [168-127]. As of 2009, Isetan-Mitsukoshi was Japan's biggest department-store operations, with sales of 1.43 trillion yen ( $\$ 15.85$ billion) in the Fiscal Year 20082009 [121].

In total, the Mitsui's operations, centered on banking, international trade, retail, and mining, represented Japan's largest pre-war 'Zaibatsu' (industrial conglomerates), and one of the world's largest corporations [124]. Today, complementing its core holdings, Mitsui contains divisions in chemicals, shipbuilding, real estate, and smelting, while Mitsui Bussan (Mitsui \& Co., Ltd.) has remained Japan's second largest trading company behind Mitsubishi. All of which were provoked by the entrepreneurial spirit of the $17^{\text {th }}$ Century leaders of the Mitsui family.

\section{The Merchants of Omi}

As for the merchants of Omi, they have long been known as Japan's traveling salesmen, whose extroverted and entrepreneurial trading activities have been chronicled as far back as the Kamakura Period (1185-1333). [101]. Omi became a prominent merchant center during the late- $16^{\text {th }}$ Century, under the reigns of the Shoguns Nobunaga Oda and Hideyoshi Toyotomi. During the Tokugawa Period, Omi merchants gained notoriety for their travels along the Nakasendo Highway, where they were frequently seen carrying backpacks larger than themselves, filled with yarn, medicines, crops, and specialty products from distant places, for sale to anyone willing to part with some money [128]. ${ }^{10}$ Along with the Tokaido, the Nakasendo was one of the nation's two most important trails, connecting eastern Japan and Edo with the western half of the country and the then Imperial capital, Kyoto. It contained numerous 'Shukuba' (post towns) with inns accommodating the feudal lords, samurai, and ordinary citizens traveling back and forth from Edo, as part of the Shogun's alternative residence policy [122, 129, 130].

Omi merchants took pride in exploring new places outside of their home territory, purchasing regional specialties to bring to Kyoto and other cities, where they exchanged them for finished goods, which they then sold in new towns or in those in which they already had established trading relationships. As a result, Omi became the ancestral birth place for the major trading companies Marubeni and Itochu, and the major department store chains Shirokiya, Takashimaya, and Seibu. Shirokiya was established in 1662, when its founder, Hikotaro Omura of Omi, opened a kimono store in the Nihombashi District of Edo [113]. In 1958, after nearly three centuries of success, Shirokiya Department 10 The Nakasendo Highway or Trail was approximately $534 \mathrm{~km} \mathrm{(332} \mathrm{mi)} \mathrm{and} \mathrm{ran}$
through parts of seven current prefectures: Tokyo, Saitama, Gumma, Nagano, Gifu, Shiga, and Kyoto. It had 67 post town stations between Tokyo and Kyoto [128]. 
Stores were taken over by Tokyu, the large railway and land development group, which has built its retail division into one of Japan's ten largest department store chains [113].

The forerunners to Takashimaya, Marubeni, and Itochu were established in the early-to-mid-19th Century. Seibu, the foundation of Seibu Department Stores, Seiyu Superstores, Seibu Railway, and the Saison Group, was founded by Yasujiro Tsutsumi during the early- $20^{\text {th }}$ Century. Although his Tsutsumi's social life was far from ascetic, according to $\mathrm{Ha}-$ vens [131], he was greatly influenced by the teachings of the earlier mentioned $18^{\text {th }}$ Century merchant turned philosopher, Baigan Ishida, who hailed from Omi. Ironically, greed would be the undoing of the Tsutsumi family empire, as following a 2003 scandal involving his sons, the Seibu-Saison Group, was dismantled. As a result, Wal-Mart of the USA took control of the Seiyu Superstores in 2005, and the financial services portion of the Saison Group, known as Credit Saison, became part of the Mizuho Financial Group. Seibu Department Stores was acquired by Seven \& i Holdings, Co., Ltd., now Japan's largest retail conglomerate. Seven \& i Holdings' subsidiaries currently include, among others: the Seibu and Sogo department stores chains, The Loft, the Ito-Yokado general merchandise/grocery superstores, and the giant American established convenience store chain, 7-Eleven. In the fiscal year ending in February 2009, Seven \& i recorded sales revenues of 5.65 trillion yen (or $\$ 62.78$ trillion) [132]. ${ }^{11}$

\section{The Merchants of Settsu-Izumi (Osaka-Sakai)}

As the cases of J. Front Retailing, Takeda Pharmaceutical, and the previously cited Sumitomo suggest, nowhere has better exemplified Japan's historical spirit of capitalism than the Settsu-Izumi Area (now/Osaka-Sakai). From at least the $17^{\text {th }}$ through the early-20 $0^{\text {th }}$ Century, this area served as the nation's commercial capital; its merchants began controlling the country's rice trade some two centuries or more prior to that. According to Mosk [118], by the 1670s, Settsu-Izumi merchants were active in trading cotton, oils, paper, firewood, charcoal, fish, fowl, swords, and copper smelting, among other products. During this time, they also established standards for accounting and bookkeeping, developed futures markets, and were providing insurance.

As Sansom [103] wrote:

The population of Osaka was in many respects different from that of Edo. Osaka had a longer history [and]...was a commercial and not a political or military center. Its citizens were nearly all engaged in trade and grew in numbers while it developed from simple beginnings as a local market to become a national emporium, attracting goods to its warehouses from most parts of the country and distributing them widely by land and by sea. The earliest great merchants in Osaka were those who, (in competition with merchants in Sakai), made fortunes as war contractors for Hideyoshi....

\footnotetext{
${ }^{11}$ After years of financial difficulties, Southland Corporation, the American-based parent of 7-Eleven worldwide, was taken over by Ito-Yokado and Seven-Eleven Japan Co., the latter of which was its largest franchisee [132].
}

[During this] period the prominent Osaka merchants were prosperous members of respectable families who filled positions as City Elders (Toshiyori) with dignity. But as the city developed, thanks to certain improved methods of transport..., a change took place in the character of its citizens. A new class of trader appeared..., for the most part newcomers, who were from the farms of Yamato, Kawachi, Izumi, and Settsu, determined to become rich by their own exertions... There is no doubt that the citizens of Osaka composed a pleasureloving society, fond of good food and sentimental plays. But as a class, the Osaka merchants were serious, hard-working men, and Osaka life in all classes was penetrated by an urgent desire for profit. In this last respect, it differed from the dominant warrior society of Edo, in which money-making was despised.

Now based in Osaka, J. Front Retailing traces its roots to the origins of two giant retailers: Matsuzakaya, which was founded in Nagoya in 1611 as a kimono fabric and fancy goods wholesale store; and Daimaru, an Osaka city based department store chain which was established as a drapery shop in 1717 by Shokei Shimomura. Born in Settsu in 1688, but raised in the Fushimi district of Yamashiro no kuni (now Kyoto city, Kyoto prefecture), Shimomura was the son of a merchant who owned a second-hand goods store. He began his own commercial training at age-11, apprenticing for his brother at a pawn and clothing rental shop. After many years of helping his brother, he opened his own store. His business prospered, and with the proceeds he joined forces with another shopkeeper to open a second store, this time in Osaka [133]. This was a common occurrence at the time, as during the early- $18^{\text {th }}$ Century, many Fushimi merchants were relocating to Osaka, which was rapidly growing larger than Kyoto under the impetus of the Tokugawa regime [116].

After splitting with his partner in the 1730s, Shimomura renamed his Osaka establishment Daimaruya. For the next two centuries, this Shinsaibashi location would serve as the centerpiece of the Daimaru Department Store chain, which operates stores in several Japanese cities [133]. As of its February 2007 annual report, Daimaru had 835.52 billion yen in sales (or $\$ 9.28$ billion) [134]. Then, on September 3, 2007, it merged with Matsuzakaya, which had sales of roughly 335 billion yen ( $\$ 3.72$ billion). As a result, the newly created J-Front Retailing vaulted past Takashimaya (a company founded by an Omi businessman in 1831), to the top of Japan's department store chains, with combined sales of 1.17 trillion yen ( $\$ 13.00$ billion). Its top position was short-lived, however, as it was surpassed on April 1, 2008 by the aforementioned Mitsukoshi-Isetan merger [135]. ${ }^{12}$

Next, Takeda Pharmaceutical Co. Ltd. offers a prime example of how a merchant's connections to Osaka transformed a family firm into a manufacturing empire. Takeda was founded in 1781 as an herbal medicine wholesaler by Chobei Takeda, in Osaka, the center of the medicine trade in Japan. The firm remained fairly localized until the 1870 s,

\footnotetext{
${ }^{12}$ In addition to general merchandising, J. Front's operations also include credit services, direct marketing, furniture making, restaurants, and wholesale textiles [134].
} 
when Takeda's great-grandson, taking advantage of the country's opening to the West, established ties with American and European companies to import Western medicines to Japan [136]. In 1895, the company opened a factory in Osaka, manufacturing pharmaceuticals for the Japanese market. Over the 50 years, it expanded significantly, and by the mid-1940s, it had introduced its own patented products. Ever since, the firm has established a global reputation for its prostate cancer, acid reflux/ulcer, hypertension, and Type-2 diabetes drugs, and has a global manufacturing, R\&D, and marketing presence in North America, and in several Western European and Southeast Asian countries. Still based in Osaka city, Takeda has grown to become Asia's largest pharmaceutical manufacturer. As of its Fiscal Year 2008 Annual Report, it had net sales of over 1.37 trillion yen (\$15.28 million) [136].

As for Sumitomo, it traces its origins back to 1590, when Riemon Soga opened a pioneering copper refinery called Izumiya in Kyoto. According to the website of Sumitomo Electric Industries [137], prior to Soga's discovery, Japanese copper merchants were unable to extract silver from copper ore; therefore, they had to export the ore with the silver intact. In 1623, Soga's eldest son, Tomomochi started his own copper works in Osaka. It was at about this time that Tomomochi also married into the Sumitomo family. Under Tomomochi, the now consolidated Sumitomo Empire expanded into copper smelting, metals processing, finance, and the trading of textiles, sugar and medicines [115, 125, 138].

By the late- $17^{\text {th }}$ Century, Sumitomo became one of its trusted financiers of the Tokugawa Bakufu, whom the family was operating a copper mine. In exchange, the firm was granted, along with a select few other companies, special copper trading privileges. Over the remainder of the Tokugawa Period, the Sumitomo family businesses would become Osaka's most dominant business conglomerate, and it, and the City of Osaka's other refining businesses, would turn Japan into one of the world's leading copper producing countries [139].

During the early Meiji Period, Sumitomo would suffer several setbacks. However, over the next 140 years it flourished into one of Japan's largest pre-war Zaibatsu and postwar 'Keiretsu' business groups [124, 125]. As of the Fiscal Year ending March 31, 2009, the Sumitomo Group's companies employed more than 70,000 people and earned revenues of 3.52 trillion yen ( $\$ 39.11$ billion), with gross profits of 935.23 billon yen ( $\$ 10.4$ billon) [139]. In that year, the family name appeared on 23 companies listed on the first section of the Tokyo Stock Exchange [140]. Among these were the world's largest manufacturer of high-end metallic titanium, the world's second largest semiconductor business, and the globe's fourth largest trading company. Moreover, its namesakes were Japan's largest general contractor (with Mitsui), single-family home builder, producer of electric wires and cables, and aluminum rolling firm. The group also contained Japan's second largest bank (i.e., SMBC), automobile tire-maker [including Dunlop Tire abroad], chemical manufacturer, and non-life insurer (with Mitsui), as well as its third largest crude steel producer, a major real estate company, and one of Japan's largest mining and smelting operations; the latter was the modern day successor to Soga's original firm [127, 141, 142].
Finally, in the early- $21^{\text {st }}$ Century, private firms established by Japanese entrepreneurs have substantial global positions in banking (Mitsubishi UFJ), trade (Mitsui), and convenience retail (Seven \& i), as well as motor vehicles (Toyota, Honda, Denso), optical devices/precision instruments (Canon, Ricoh, Seiko Epson), home electronics/entertainment (Panasonic, Sony, Nintendo), chemicals (Sumitomo, Mitsui), metals (Nippon Steel, JFE, Sumitomo), pharmaceuticals (Takeda), and ceramics (Noritake) manufacturing, among others. Although certainly aided by the policies of a supportive developmental government, if Weber were alive today, these facts would have most assuredly persuaded him to acknowledge how Japan's rich history of entrepreneurship was vital to that nation's past and present capitalist development.

\section{CONCLUSION: JAPAN PROVES WEBER RIGHT AND WRONG}

Max Weber was right to conclude that hard work, asceticism, and a strong entrepreneurial spirit were necessary embedded preconditions to capitalist development. What he was wrong about was Japan, and its ability to develop such an ethic. As chronicled in this article, similar to Weber's Protestant Ethic, Japan's nested context has also fostered a propensity to work long hours (hard work), and to maintain high savings rates (asceticism). It also has been a fertile crucible for entrepreneurship, with a rich history of profit-motivated merchants dating back more than 400 years.

In reference to long working hours, clearly, an initial force in the post-war period provoking this phenomenon was the rebuilding of the country following the devastation of World War II. Nevertheless, as discussed, Japan has a history of hard work that predates World War II, fostered by a number of embedded factors. Most prominent among them have been a: 1) 'catch-up' nationalist ideology, first instilled during the 1868 Meiji Restoration; 2) hegemonic politicosocial context which has stressed filial piety; and 3) postWorld War II segmented internal labor market, which has both demanded devotion to firm while severely inhibiting labor mobility.

During the Meiji period, catch-up nationalism rested upon three principles: 'fukoku kyouhei,' national wealth as the basis of national strength; 'banpou taiji,' to stand up against all other countries; and 'shokusan kougyou', the nurturing and protecting of domestic industry from outside forces. In the post-war period, it has focused solely on economic nationalism. Similarly, a post-war wrinkle to Japan's traditional hegemony of filial piety that has induced long working hours has been sempai-kohai relations among colleagues of the same firm. These have bound worker to firm through the creation of a new master for which to demonstrate loyalty to.

Next, the three pillars of Japan's labor market, lifetime employment, profit sharing bonuses, and seniority wages, have also provoked labor to commit to long working hours. These elements have done so in concert with sempai-kohai relations, by providing what Weber claimed was another important aspect of his Weber's Protestant Ethic: a strong sense of trust outside the family. However, in addition to building extra-familial trust, the three pillars also have contributed to the creation of a hierarchical and segmented labor 
market in Japan, one which has severely limited worker employment mobility. They have done so by, among other things, instilling fear in labor- a fear of job security, declining wages, status, and self-esteem- and out of a perceived and real lack of comparable job alternatives. This has been the case, in spite of Japan's tremendous post-war economic success, and implied guarantees by the company of lifetime employment. Such an environment then has enabled management to extract an even greater employee willingness to work more hours.

Among the embedded factors influencing high savings rates/asceticism in Japan have been: 1) a relatively 'small' government as compared with the USA and UK, especially for national defense; 2) the aforementioned worker compensation system which has promoted austerity among households by deferring salary through semi-annual bonuses; 3 ) an under-financed social security system; and 4) national government policies that have severely suppressed consumption. Examples of the latter briefly discussed in this article were the Japanese Government's strict regulations on consumer credit, its high tariffs and trade barriers to protect domestic manufacturers by discouraging the purchases of imports, and its inflation/fixing of domestic prices, in order to subsidize the exports of Japanese firms in strategic industries. All of these elements have forced Japanese citizens to save more than residents of the two largest Anglo-nations, the USA and $\mathrm{UK}$, in order to purchase both daily necessities and big-ticket items.

Finally, as discussed, well prior to Weber's writing, Japan had both the rational money economy and entrepreneurial skills necessary to develop capitalism. By the mid- $19^{\text {th }}$ Century, cities and villages all over the nation had merchants and farming families with side businesses established with the primary purpose of accumulating wealth. As described, perhaps the best examples of this more than 400-year rich history have been the merchants of Ise, Omi, Osaka-Sakai (Izumi-Settsu). The latter area, long known as the 'Manchester of the Orient,' has had a vibrant mercantile class since roughly the $15^{\text {th }}$ Century, and served as Japan's commercial capital from roughly the mid- $17^{\text {th }}$ Century until the around the early- $20^{\text {th }}$ Century.

In closing, perhaps Japan was an enigma for Weber, a contradiction to his theories which he either could not comprehend, or was unwilling to accept [143]. As a result, he ignored the fact that, while China, Japan, and South Korea were all founded upon principles derived from the Analects of Confucius, each had its own uniquely embedded history and culture which greatly influenced the degree and style of Confucianism which each country adapted to its particular society. Overall, as a result of Weber concluding that all Confucian nations were the same, he ignored his own findings from the Protestant Ethic, that nested factors had driven the development of capitalism in Protestant nations [144]. Japan has also long valued hard work, asceticism, and entrepreneurialism, and just as was the case for Weber's Calvinists, its embedded context, its Japanese Ethic, was vital to the emergence and rise of capitalism in that East Asian, nonProtestant nation.

\section{ACKNOWLEDGMENTS}

The author would like to thank Jennifer B. Jacobs, Shuko K. Jacobs, Ambreen Mehboob, the editor and editorial assis- tants of TOARSJ, and the anonymous reviewers for their comments and suggestions related to this article.

\section{REFERENCES}

[1] (a) Marx K. Contribution to the critique of political economy. New York: International Publishers 1972; and (b) Marshall G. Oxford dictionary of sociology. New York: Oxford University Press 1998.

[2] Giddens A. Introduction. In: Weber M, Ed. The Protestant ethic and the spirit of capitalism. New York: HarperCollins Academic 1992.

[3] Giddens A. Politics, sociology, and social theory. Stanford: Stanford University Press 1995.

[4] Morishima M. Why has Japan succeeded? Western technology and the Japanese ethos. Cambridge: Cambridge University Press 1982.

[5] Morishima M. Confucius and capitalism. UNESCO Cour 1987; (12): 34-37.

[6] Morishima M. Ideology and economic activity. Curr Soc 1990; 38 (2): 51-77.

[7] Morishima M. Japan at a deadlock. New York: St. Martin's Press 2000.

[8] Granovetter M. Economic action and social structure: the problem of embeddedness. Am J Sociol 1985; 91 (3): 481-510.

[9] Swedberg R. Max Weber and the idea of economic sociology. Princeton, NJ: Princeton University Press 1998.

[10] Swedberg R. Max Weber's vision of economic sociology. J SocioEco 1998; 27(4): 535-55.

[11] Freund, J. The sociology of Max Weber. New York: Pantheon Books 1968.

[12] Weber M. The protestant ethic and the spirit of capitalism. New York: Routledge 1992.

[13] Weber M. From Max Weber: essays in sociology. In: Gerth H, Mills CW, Eds. New York: Oxford University Press 1946.

[14] Weber M. Weber: selections in translation. In: Runciman WG, Eds. NY: Cambridge 1978.

[15] Weber M. Sociology of religion. Boston: Beacon Press 1991.

[16] Weber M. Economy and society. In: Roth G, Wittich C, Eds. New York: Bedminster 1978.

[17] Weber M. The religion of China: confucianism and taoism. Glencoe: The Free Press 1951.

[18] Mouer R, Kawanashi H. A sociology of work in Japan. NY: Cambridge Univ. Press 2005.

[19] Cabinet Office. Sankouzu 5-1: Nenkan Sourodou Jikan no Suii, 1905-1995 [Reference Chart 5-1: Change in Total Annual Actual Working Hours per Worker, 1905-1995]. Tokyo: Kokumin Seikatsu Shingikai [Citizens Life Council]. Government of Japan [Online]. 2006. Available from: http://wp.cao.go.jp/zenbun/kokuseishin/spc15/houkoku_a/spc15-houkoku_a-ref2.html\#5-1, retrieved 2009 Nov 6.

[20] Fitzgerald T. Reducing working hours. Econ Rev (Cleveland) 1996; 32(4): 13-22.

[21] Ministry of Labor. Changes in total annual working hours per worker. Tokyo: Government of Japan, Ministry of Health, Labor and Welfare [Online] 1999. Available from: http://www2.mhlw.go. jp/english/e_text/outline/fgr-tbl/t4-2-2.htm, retrieved 2009 Nov 25.

[22] See three publications by the Japan's Ministry of Health, Labor, and Welfare: 1) Monthly Labor Surveys; 2) 2008 Basic Survey on Wage Structure; and 3) Nenkan roudou jikan no suii: Jigyousho kibo 30-nin ijou [Annual working hours: Establishments with 30 or more employees], 1971-2008: Tokyo: Government of Japan, Ministry of Health, Labor and Welfare [Online] 2009. All available from: http://www.mhlw.go.jp, retrieved 2010 January 8.

[23] OECD. OECD employment and labor market statistics: Average annual hours actually worked per worker V2008 release 01. Paris, OECD [Online]. 2009. Available from: http://oecd.org, retrieved 2009 Nov 23.

[24] OECD. OECD employment outlook 2009. Paris: OECD, June.

[25] Linhart S. From industrial to postindustrial society: changes in Japanese leisure-related values and behavior. In: Large SS, Ed. 
Showa Japan: Political, economic and social history 1926-1989, vol IV, 1973-1989. New York: Routledge 1998; pp. 212-44.

[26] Government of Japan. Japan's labor standards law, chapter IV, pp. 32-41: Working hours, rest periods, rest days, and annual leave with pay 2009.

[27] Government of Japan. Realization of meaningful, secure employment for workers. Tokyo: Ministry of Labor [Online] 1999.

Available from: http://www2.mhlw.go.jp/english/e_text/outline/042.htm, retrieved 2009 Nov 23.

[28] JETRO. Nippon 1997 Business facts \& figures. Tokyo: JETRO 1997.

[29] Akamatsu K. A historical pattern of economic growth in developing countries. Dev Econ 1962; Preliminary 1 (Mar-Aug): 3-25.

[30] Marshall BK. Capitalism and nationalism in prewar Japan: The ideology of the business elite. Stanford: Stanford University Press 1967.

[31] Kojima K. Japan and a new world economic order. Boulder Westview Press 1977.

[32] Murakami Y. Toward a socioinstiutional explanation of Japan's economic performance. In: Yamamura K, Ed. Policy and trade issues of the Japanese economy: American and Japanese perspectives. Seattle: University of Washington Press 1982; pp. 3-45.

[33] Dore R. Flexible rigidities: industrial policy and structural adjustment in the Japanese Economy 1970-1980. Stanford, CA: Stanford University Press 1986.

[34] Dore R. Taking Japan seriously: a confucian perspective on leading economic issues. Stanford: Stanford University Press 1987.

[35] Lee CH, Yamazawa I, Eds. The economic development of Japan and Korea: A parallel with lessons. New York: Praeger 1990.

[36] Yamazawa I. Economic development and international trade: the Japanese model. Honolulu: East-West Center Resources Systems Institute 1990

[37] Kumon S, Rosovsky H, Eds. The political economy of Japan. Cultural and social dynamics. Stanford: Stanford University Press 1992; vol. 3.

[38] Nakane C. Japanese society. Berkeley: University of California Press 1970.

[39] Woronoff J. Japan: the coming economic crisis. Tokyo: Yohan Publications 1979

[40] Woronoff J. Japan: the coming social crisis. Tokyo: Yohan Publications 1980.

[41] Odaka, K. Sangyou shakaigaku kougi [Lectures on industrial sociology]. Tokyo: Iwanami Shoten 1981.

[42] Reischauer EO. The Japanese today. Tokyo: Charles E. Tuttle Company 1988.

[43] Matsumoto K. The rise of the Japanese corporate system. New York: Kegan Paul 1994.

[44] Fingleton E. Blindside. Why Japan is still on track to overtake the U.S. by the year 2000. Tokyo: Kodansha International 1995.

[45] Woronoff J. The Japanese social crisis. New York: St. Martin's Press 1997.

[46] Reed SR. Making common sense of Japan. Pittsburgh: University of Pittsburgh Press 1993.

[47] Koike K. The economics of work in Japan. Tokyo: LTCB International Library 1995.

[48] Gordon A. The wages of affluence: Labor and management in postwar Japan. Cambridge: Harvard University Press 1998.

[49] Ministry of Economy, Trade and Industry, Small and Medium Enterprise Agency. Outline of the small and medium enterprise basic law. Tokyo: Government of Japan, [Online] 2009. Available from: http://www.chusho.meti.go.jp/sme_english/outline/02/01. html, retrieved 2009 Nov 14.

[50] Samuels RJ. Rich nation, strong army: National security and the technological transformation of Japan. Cornell: Cornell University Press 1994.

[51] Patrick H, Ed. Japanese industrialization and its social consequences. Berkeley: University of California Press 1976.

[52] Allen GC. The Japanese economy. New York. St. Martin's Press 1981.
[53] Allen GC. A short economic history of Japan, $4^{\text {th }}$ ed. London. MacMillan 1981.

[54] Shinohara M. Industrial growth, trade, and dynamic patterns in the Japanese economy. Tokyo: University of Tokyo Press 1982.

[55] Johnson C. MITI and the Japanese miracle: the growth of industrial policy, 1925-1975. Stanford: Stanford University Press 1982.

[56] Hill RC, Lee YJ. Japanese multinationals and east Asian development. In: Sklair L, Ed. Capitalism \& development. New York: Routledge 1994; pp. 289-315.

[57] Huber TM. Strategic economy in Japan. Boulder: Westview Press 1994.

[58] Yoshihara K. Japanese economic development, $3^{\text {rd }}$ ed. New York: Oxford 1994.

[59] Nakamura T. The postwar Japanese economy: Its development and structure, 1937-1994, second edition. Tokyo. University of Tokyo Press 1995.

[60] Gao B. Economic ideology and Japanese industrial policy: Developmentalism from 1931 to 1965 . New York: Cambridge University Press 1997.

[61] Sumiya M, Ed. A history of Japanese trade and industrial policy. New York: Oxford 2000.

[62] Befu H. Hegemony of homogeneity: an anthropological analysis of Nihonjinron. Melbourne: Trans Pacific Press 2001.

[63] Gramsci, A. Selections from the prison notebooks of Antonio Gramsci. In: Hoare Q, Smith GN, Eds. New York: International Publishers 1999; p. 12.

[64] McCormack G. The emptiness of Japanese affluence. Armonk, NY: M.E. Sharpe 1996.

[65] Sugimoto Y. An introduction to Japanese society, New York: Cambridge 2003.

[66] Goffman E. The presentation of self in everyday life. NY: Anchor Books 1959 .

[67] Smith RJ. Japanese society: Tradition, self, and social order. New York: Cambridge 1983.

[68] Ono H. Lifetime employment in Japan: concepts and measurements. (SSE/EFI Working Paper Series in Economics and Finance No. 24). Stockholm: Stockholm School of Economics 2007 Mar.

[69] The Japan Institute for Labor Policy \& Training. Japanese working life profile 2008/2009- Labor statistics. Tokyo: JILPT 2008.

[70] Abegglen J, Stalk G Jr. Kaisha: the Japanese corporation. New York: Basic Books 1985.

[71] Fukuyama F. Trust: the social virtues and creation of prosperity. NY: The Free Press 1995.

[72] Nonaka I, Takeuchi H. The knowledge-creating company: Japanese companies create the dynamics of innovation. New York: Oxford University Press 1995.

[73] Fujita K, Hill RC. Innovative Tokyo. Report prepared for the World Bank Workshop on Creative Industries in East Asia East Lansing, MI 2004 Feb 22-23.

[74] Japan Institute for Labor Policy \& Training. Labor situation in Japan and analysis: Detailed exposition 2009/2010. Tokyo: JILPT [Online]. 2009. Available from: http://www.jil.go.jp, retrieved 2009 Nov 18.

[75] Japan Institute for Labor Policy \& Training. Labor situation in Japan and analysis: 2004/ 2005. Tokyo: JILPT [Online]. 2004. Available from: http://www.jil.go.jp, retrieved 2009 Nov 18.

[76] Japan Institute for Labor Policy \& Training. Signs of a favorable reappraisal of Japanese-style employment practices. The Japan Labor Flash 2005, May 2 [Retrieved 2009 Nov 14]. Available from: http://www.jil.go.jp/foreign/emm/no.37/37_si.htm.

[77] Passet O. Stability and change: Japan's employment system under pressure. In: Auer P, Cazes S, Ed. Employment stability in an age of flexibility. Geneva: ILO 2002.

[78] OECD. Jobs for Youth: Japan. Paris: OECD 2009.

[79] Ministry of Health, Labor and Welfare, Human Resources Development Bureau. Report from the research association on lifelong career development support and corporate organization. Temporary Translation. Tokyo: Government of Japan [Online]. 2007 Jul 20. 
Available from: www.mhlw.go.jp/english/policy/development/ 01/pdf/03.pdf, retrieved 2009 Nov 14.

[80] Shimomitsu T. Occupational stress and health in Japan, AsianPacific Newsletter 1999, Jan. Helsinki: Finnish Institute of Occupational Health [Retrieved 2009 Nov 25. Available from: http://www.ttl.fi/Internet/English/Information/Electronic+journals/ Asian-Pacific+Newsletter

[81] Thurow L. Head to head: the coming economic battle among Japan, Europe, and America. New York: Warner Books 1992.

[82] Abegglen J. Sea change: pacific Asia as the new world industrial center. NY: The Free Press 1994.

[83] Bridges B. Japan and Korea in the 1990s: from antagonism to adjustment. Brookfield, VT: Edgar Elgar 1990.

[84] Minami R. The economic development of Japan: a quantitative Study, second edition. New York: St. Martin's Press 1994.

[85] OECD. OECD Economic outlook 1981. Paris: OECD, No. 29, Jul.

[86] OECD. OECD Economic outlook 1982. Paris: OECD, No. 52, Dec.

[87] OECD. OECD Economic outlook 2001. Paris: OECD, No.70, Dec.

[88] OECD. OECD Economic outlook 2009. Paris: OECD, No. 85, June.

[89] OECD. OECD Economic outlook 1987. Paris: OECD, No. 41, June.

[90] OECD. OECD Economic Outlook, Annual and quarterly data, V2009, release 01, online database. Paris: OECD [Online]. 2009. Available from: http://oecd.org, retrieved 2009 Sept 25.

[91] Yamamoto S. The spirit of Japanese capitalism: and selected essays. Tokyo: The Pacific Basin Institute 1992.

[92] Bellah RN. Tokugawa religion: the cultural roots of modern Japan. New York: Free Press 1985

[93] Lockwood WW. The economic development of Japan, expanded edition. Princeton: Princeton University Press 1968.

[94] Allen GC. Japan's economic recovery. New York: Oxford University Press 1958.

[95] Johnson C. Who governs Japan? New York: W. W. Norton \& Company 1995.

[96] Mikuni A, Murphy RT. Japan's policy trap: dollars, deflation, and the crisis of Japanese finance. Washington: Brookings Institute Press 2003.

[97] Hook GD, Gilson J, Hughes CW, Dobson H. Japan's international relations: Politics, economics and security. New York: Routledge 2005.

[98] See Jacobs, AJ. Embedded localities: employment decline, inner city population growth, and declining place stratification among Japan's mid-size and large cities. City Com 2006; 5 (3): 269-292. For historical currency rates, see the Oanda Company website. Available from: http://www.oanda.com.

[99] Ministry of Internal Affairs and Communication. 2006 establishment and enterprise census of Japan. Tokyo: Government of Japan [Online] 2008. Available from: http://www.stat.go.jp/index.htm, retrieved 2009 Nov 18.

[100] Management and Coordination Agency. 1991 establishment and enterprise census of Japan. Tokyo: Government of Japan, Management and Coordination Agency 1992.

[101] Sansom G. A history of Japan: 1334-1615. Stanford: Stanford University Press 1963.

[102] Meyer MW. Japan: a concise history, $4^{\text {th }}$ ed. Lanham, MD: Rowan \& Littlefield 2009.

[103] Sansom, G. A history of Japan: 1615-1867. Stanford: Stanford University Press 1963.

[104] DeMente BL. Japan encyclopedia. Lincoln, IL: Passport Books 1995.

[105] Yamamura K, Ed. The economic emergence of modern Japan. New York: Cambridge University Press 1997.

[106] Hirschmeier J. Shibusawa Eiichi. In: Lockwood WW, Ed. The state and economic enterprise in Japan. Princeton: Princeton University Press 1965; pp. 209-47.

[107] Patrick H, Rosovsky H, Eds. Asia's new giants: How the Japanese economy works. Washington: The Brookings Institute 1976.
[108] Myers RH, Peattie MR, Eds.The Japanese colonial empire, 18951945. Princeton: Princeton University Press 1984.

[109] Duus P, Myers RH, Peattie MR, Eds. The Japanese informal empire in China, 1895-1937. Princeton: Princeton University Press 1989.

[110] Beasley WG. The rise of modern Japan: political, economic and social change since 1850. New York: St. Martin's Press 1995.

[111] Giddens A. A contemporary critique of historical materialism. Vol 1: Power, property and the state. Berkley: University of California Press 1981.

[112] Yamamura K.The founding of Mitsubishi: a case study in Japanese business history. Bus Hist Rev 1967; 41(2): 141-60.

[113] McClain JL. Japan: A modern history. New York. W.W. Norton \& Company 2002.

[114] Eyre, JD. Nagoya: the changing geography of a Japanese regional metropolis. Chapel Hill: University of North Carolina 1982.

[115] Hill RC, Fujita K. Osaka's Tokyo problem. Int J Urb Reg Res 1995; 19(2): 181-93.

[116] McClain JL, Wakita O, Eds. The Merchants' Capital of Early Modern Japan. Ithaca, NY: Cornell University Press 1999.

[117] Edgington D. Osaka Profile. Cities 2000; 17(4): 305-18.

[118] Mosk C. Japanese industrial history: Technology, urbanization, and economic growth. Armonk, NY: M.E. Sharpe 2001.

[119] Roberts JG. Mitsui: three centuries of Japanese business. New York: Weatherhill 1973.

[120] AEON. AEON History [Online]. 2009. Available from: http://www.aeon.info/en/aboutaeon/history.html retrieved 2009 Oct 22.

[121] Isetan Mitsukoshi Holdings Isetan Mitsukoshi holdings results for FY2008. [Online]. 2009. Available from: http://www.imhds.co.jp/ english/ir/pdf/investor_relations/hds/2009/0702_SSCA_March_03. pdf. Retrieved 2009 Oct 3.

[122] Jacobs AJ. Devolving authority and expanding autonomy in Japanese prefectures and municipalities. Governance 2003; 16(4): 60123.

[123] Morikawa H. Zaibatsu: the rise and fall of family enterprise groups in Japan. Tokyo: University of Tokyo Press 1992.

[124] Miyashita K, Russell D. Keiretsu: inside the hidden Japanese conglomerates. New York: McGraw-Hill 1996.

[125] Sumitomo Mitsui Banking Corporation. Company profile. [Online]. 2009. Available from: http://www.smbc.co.jp/aboutus/ english/profile/company.html, retrieved 2009 Oct 4 . All currency converted using October 2009 exchange rates of 90 yen to 1 U.S. Dollar.

[126] Isetan Group. Isetan CSR report 2007. Tokyo: Isetan Group 2007.

[127] Toyo Keizai Inc. Japan company handbook: first section. Tokyo: Toyo Keizai Inc 2006.

[128] Stanley TA, Irving RT. Nakasendo way. Omi merchants. [Online]. 2008. Available from: http://www.nakasendoway.com/omimerch. xhtml, retrieved 2009 Oct 6.

[129] Omiya city. Omiya machi monogatari [Omiya town story]. Omiya, Japan: Mayor's Office of the Mayor, Public Relations Division 2000.

[130] Jacobs AJ. Learning cities, the creative class, and economic embeddedness: a comparison of Columbus $(\mathrm{OH}) \&$ Saitama (Japan). Paper presented during the 2004 Regional \& Urban Development Research Committee Conference, Singapore 2004, December 9-11.

[131] Havens TR. The architects of influence: the tsutsumi family and the Seibu-Saison enterprises in twentieth century Japan. Cambridge: Harvard Council of East Asian Studies 1995.

[132] See Seven \& i Holdings Co., Ltd. Consolidated financial results for fiscal year ending February 29, 2009. [Online] 2009. Available from: http://www.7andi.com/en/news/pdf/20090409_01_e.pdf, retrieved 2009 Oct 9

[133] International Business Organization of Osaka. Great people of Osaka, Shokei Hikoemon Shimomura, founder of Daimaru: Profit will follow later. Osaka Business Update 2006 (4) [Retrieved 2009 Oct 29]. Available from: http://www.ibo.or.jp/en/2006_4/index. html, 
[134] Daimaru. Annual report 2007. Tokyo: J-Front Retailing 2007.

[135] The Japan Times. Daimaru-Matsuzakaya merger OK'd. 2007 May 25. Available from: http://search.japantimes.co.jp/print/ nb20070525a8.html, retrieved 2009 Oct 29.

[136] Takeda Pharmaceutical Company, Ltd. [Online] 2009. Available from: http://www.takeda. com retrieved 2009 Oct 29.

[137] Sumitomo Electric Industries. Sumitomo Electric company history. [Online]. 2009. Available from: http://www.sumicarbide.com/ aboutus.htm, retrieved 2009 Oct 29.

[138] Sumitomo Corporation. History of Sumitomo. [Online] 2009. Available from: http://www.sumitomocorp.co.jp/english/company/ history/index.html, retrieved 2009 Oct 29.

[139] Sumitomo Coporation. Annual Report. Tokyo: Sumitomo Corporarion 2009
[140] Tokyo Stock Exchange. Listed companies. [Online]. Available from: http://www.tse.or.jp, retrieved 2009 Oct 31 .

[141] Fortune Magazine. Fortune global 500 2006: Industries. [Online] 2006. Available from: http://money.cnn.com/magazines/fortune/ global500/2006/industries, retrieved 2009 Oct 30 .

[142] Fortune Magazine. Fortune global 500 Industries. 2009 [Online]. Available from: http://money.cnn.com/magazines/fortune/ global500/2009/industries, retrieved 2009 Oct 30.

[143] Morishima M. Capital and credit. New York: Cambridge University Press 1992.

[144] Dator JA. The Protestant Ethic in Japan. In: Yamamoto GK, Ishida T, Eds. Selected readings in modern Japanese society. Berkeley: McCutchan 1971.

(C) A.J. Jacobs; Licensee Bentham Open.

This is an open access article licensed under the terms of the Creative Commons Attribution Non-Commercial License (http://creativecommons.org/licenses/ by-nc/3.0/) which permits unrestricted, non-commercial use, distribution and reproduction in any medium, provided the work is properly cited. 